\title{
Analysis of the Covid-19 Impact on Electricity Consumption and Production
}

\author{
D. Mehmet Bulut ${ }^{1}$ \\ ${ }^{1}$ Electricity Generation Co, Ankara, Turkey; mehmetbulut06@gmail.com
}

Received 28 October 2020; Revised 2 December 2020; Accepted 3 December 2020; Published online 30 December 2020

\begin{abstract}
With the year 2020, the world faced a new threat that affects all areas of life, negatively affects production in all areas and paralyzes social life. The measures and restrictions taken by the country's governments to prevent the epidemic from spreading rapidly in the society with the effect of the coronavirus (Covid-19), which first appeared in China and spread all over the world, brought a new lifestyle. Covid-19 has been much the impact on electricity use and electricity production in the period in Turkey as like other countries. There was a sharp decline in commercial and industrial electricity use. The coronavirus effect has also been reflected in the electricity demand and the consumption amount has undergone a great negative change. Due to the enactment of measures against the new type of coronavirus epidemic and the partial or full-time curfews, electricity consumption was moved to homes, supermarkets and hospitals in April 2020 from places where mass consumption is intense, such as industry, workplaces and educational institutions. In this study, Covid-19 period, the first cases were examined electricity production and consumption in Turkey as of the date it is seen throughout, in comparison with electricity consumption data in the same month of the previous years corresponding to this period, the effects on electricity generation and consumption habits of this period were examined.
\end{abstract}

Keywords: Covid-19 process, Electricity production, Electricity consumption, Energy demand

\section{Introduction}

In developed countries around the world, energy consumption does not significantly increase, due to the saturation point of per capita electricity use and continuous close to the fixed value. However, as developing countries still maintain their development levels, the total electricity consumption and the amount of electricity used per person increase every year. In the same way, Turkey is a developing country. And electricity demand has a proportion of the increase with economic growth due to industrialization and urbanization. Because Turkey has an increasing population continuously with a rising trend. Due to the Covid-19 epidemic all over the world, people were forced to face a new lifestyle that they are not used to.

In countries where the first cases were seen, urgent measures forced people to rearrange their lives beyond encountering a different situation. Those who remained outside the mandatory work fields had to continue their jobs from home. Slowing down production in all sectors or stopping it completely at some points caused the electricity consumption used in the industry to decrease significantly. The change caused a change in demand and low consumption in almost all types of energy types, as not only in electricity but also in transportation, heating, and air conditioning routines.

Starting from the beginning of 2020 in the world, due to the introduction of global measures against the Covid-19 epidemic, partial or full-time curfews, electrical energy consumption has shifted from places such as industry, business and educational institutions to homes, supermarkets and hospitals. The virus has affected all aspects of social needs such as health, economy and finance, labor, education, environment, energy, defense, food and agriculture, technology and sustainability in all visible countries [1].

At the global level, electricity consumption fell by $2.5 \%$ in the first three months of 2020, but it should be noted that lockdown measures were implemented in less than a month in most countries. With full quarantine, electricity consumption was reduced by at least $20 \%$ and smaller reductions for partial 
lockouts occurred. Initial analyzes by the International Energy Agency (IEA) show that the entire year electricity demand may fall by $6 \%$, which is equivalent to the combined electricity demands of France, Italy, the United Kingdom and Germany in 2019 [2]. The weekly consumption pattern in Germany remained almost the same, albeit at a lower level, but the morning peak demand in Italy, France, Spain and Poland showed a more steady course while evening peak demand remained as before [3]. While low electricity consumption levels in the world reflect negatively on the production of fossil fuel power plants, the penetration of renewable energy in electricity grids reaches the highest levels [4]. According to the study based on data from the European Network of Transmission System Operators (ENTSO-E), Italy's electricity demand decreased by $20 \%$ after the introduction of full quarantine, while France and Spain saw a decrease of $13 \%$ and $10 \%$, respectively [5],[6].

Covid19 scope of the measures taken to combat the outbreak in Turkey, quarantine practices, the impact of such measures on energy sector changes was seen during business hours. Covid19 first case in Turkey was recorded on 11 March 2020, to withdraw from this date to people's homes and in homes with social disconnection of communication has increased electricity use. However, there was a sharp decrease in electricity use in businesses, since workplaces and manufacturing factories completely stopped their production or did partial work and production. The coronavirus effect has also reflected on the total electricity consumption demand and the consumption amount has undergone a great negative change [7].

In this study, the relationship between the Covid-19 period and electricity consumption has been examined. Examined subjects are as well as the change in electricity generation due to quarantine measures and their impact on energy resources. And after the Covid-19 process, it was studied that because of the measures were taken the people in the changes occurring form of new life, with the change of social life that how effects Turkey's energy consumption. Turkey's electricity consumption habits according to the same month of the previous year, and used resources has been studied, on the electricity production and consumption of this period, effects have been studied.

\section{Methods And Data Sources}

This data evaluation and information extraction study was prepared by gathering publicly available data published by various sources. It aims to reveal the effects of the measures taken during the Covid19 period and the change in social life on electricity generation and consumption. The data used in this study are taken on the public web of EMRA (Energy Market Regulatory Authority), EPIAŞ (Turkish Energy Exchange), TEIAŞ (Turkish Transmission System Operator), TEIAŞ Load Dispatch Center, TEDAŞ (Turkish Distribution System Operator) [8]-[12]. The graphics in this study have been obtained using the public resources of these institutions.

\section{Overview Of Development Of Turkey's Electrical Power Capacity}

With the increase in population, Turkey's economy is growing faster, it also brings in the development of industry and leads to constantly increasing energy demand. To sustain the development of the country and to meet the increasing demand for electricity energy; quality, continuous, cheap, and reliable energy resources are needed. Turkey does not have enough potential in terms of hydrocarbon reserves. However, it has many resources in terms of hydraulic power plants and has great potential in terms of renewable energy sources such as solar and wind due to its geographical location. This potential makes it even more attractive to use renewable energy potential in electricity generation. The fact that Turkey is among the emerging economies in the world, electricity consumption in developing countries due to the continuous increase of the population is expected to increase for many years.

Generally, The amount of energy consumed per capita is used as a measure of the development and welfare level of the countries. When developed countries are evaluated from this point of view, it is seen that the average energy consumption of OECD in European countries is approximately 6500 $\mathrm{kWh} /$ person and annual energy consumption per person is $10.000 \mathrm{kWh} /$ year. As shown in Figure 2, the electricity consumption per capita gross Turkey $3700 \mathrm{kWh} /$ year and net consumption of about 
$2855 \mathrm{kWh} /$ year. Electricity consumption per capita, when considering Turkey's development assessment process, it is clear that demand increased steadily in the coming years (Figure 1).

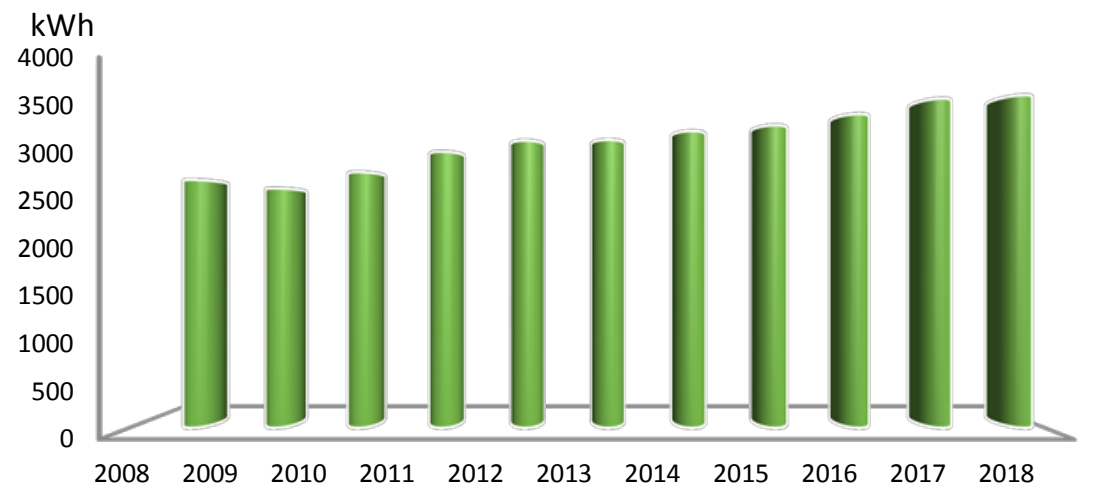

Figure 1 The change of the per capita gross electricity consumption in Turkey.

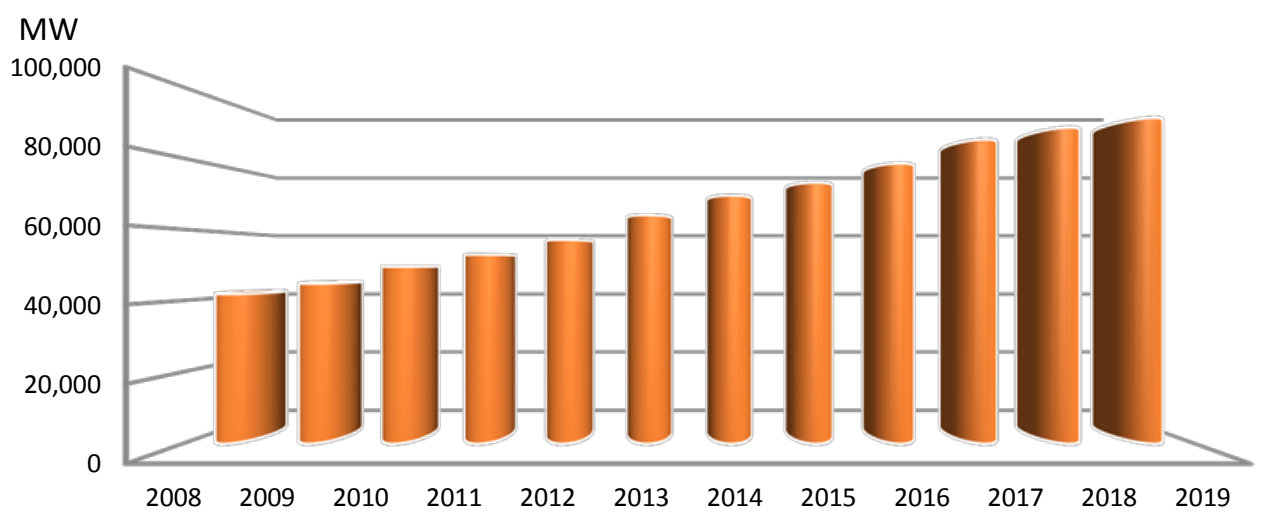

Figure 2 Changes to the years of Turkey's electricity generation capacity.

Turkey's electricity production capacity is increasing every year despite showing a slowdown in the growth rate in recent years. As seen as in Figure 2, Turkey's electricity installed capacity increased by 3.07\% compared to 2018 and reached 91267 MW at the end of 2019. Distribution of energy resources of Turkey's total generated electrical energy by the end of 2019; $28.38 \%$ are natural gas-based power plants with a capacity of 25,902.3 MW, 31.2\% are hydraulic power plants with a capacity of 20,642.5 MW and river power plants with a capacity of 7,860.5 MW. The share of coal in electricity production capacity of Turkey; $11.07 \%$ was lignite-based power plants with a capacity of $10.101 \mathrm{MW}$, and $9.82 \%$ was imported coal-based power plants with a capacity of 8.966.9 MW.

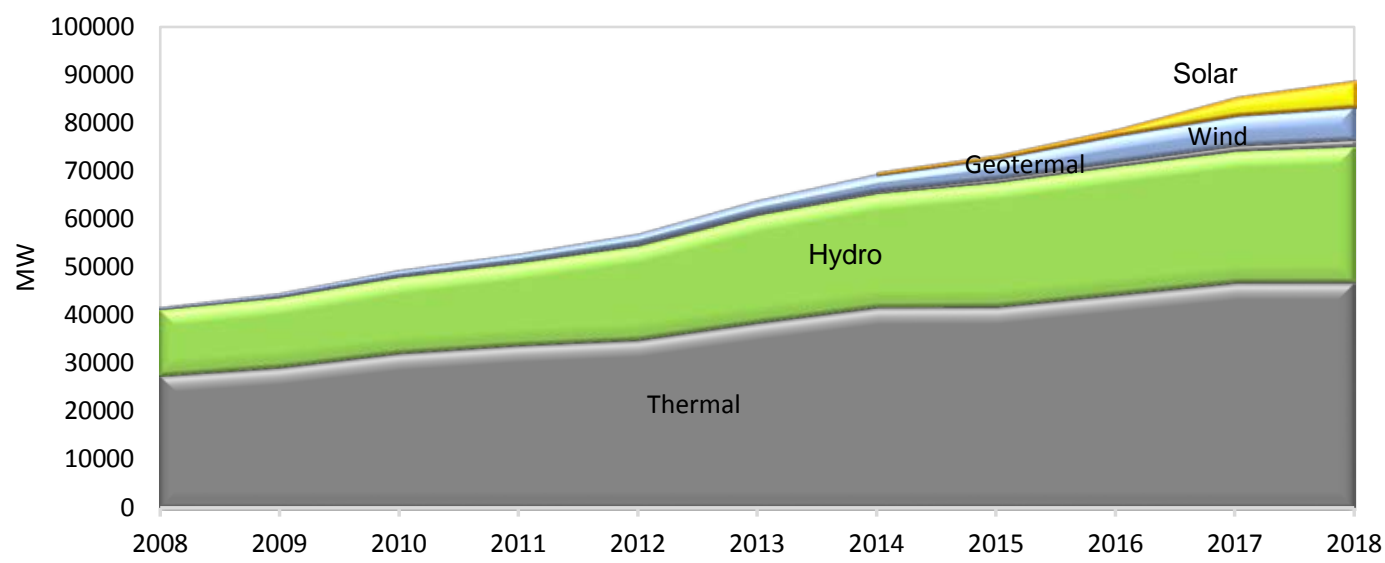

Figure 3 The change of Turkey's electricity installed capacity by years based on resources. 
As of the end of $2019,48.7 \%$ of the total installed power was effectuated by power plants producing from renewable energy sources, and their total installed power capacity reached 44,405 MW. The renewable installed capacity is hydraulic power plants with $31.2 \%$, wind power plants with $8.32 \%$, solar power plants with $6.57 \%$ and geothermal power plants with $1.66 \%$.

In 2000, Turkey's total wind power-based electricity production was 33.4 MW, reached 21317.6 MW capacity at the end of 2019 [13]. Turkey's electricity production capaci ty based on solar cells; Although the capacity value was zero in 2013, the capacity of solar power plants reached 10,794 MW at the end of 2019 (Figures 3 and 4). Turkey in wind power, although with a capacity of one third of Germany, based on the capacity of solar cell has a value of about one-fifth of Germany [14].

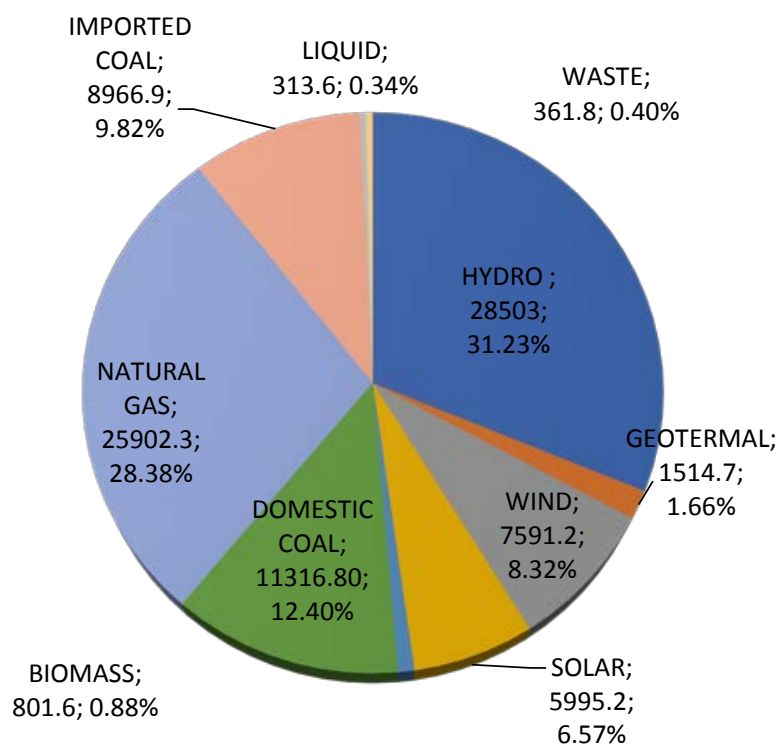

Figure 4 Turkey's electricity installed capacity (MW), according to sources at end of 2019.

The generation of electricity from wind energy in Turkey began 20 years ago, besides, within a few years of electricity from solar energy has shown rapid growth. Also, an important step has been taken to generate electricity from geothermal and bioenergy-based renewable sources. Electricity generation from renewable sources such as wind, solar and geothermal shows a rapid increase every year. Turkey's electricity demand to rise despite the continuous, whereas after 2017 due to the overall global economic recession has slowed. In Turkey, about 300 billion kWh per year in gross electricity demand is realized. Turkey in 2018, was realized as gross electricity demand with an increase of $2.5 \%$ to 304.8 billion kWh (Figure 5).

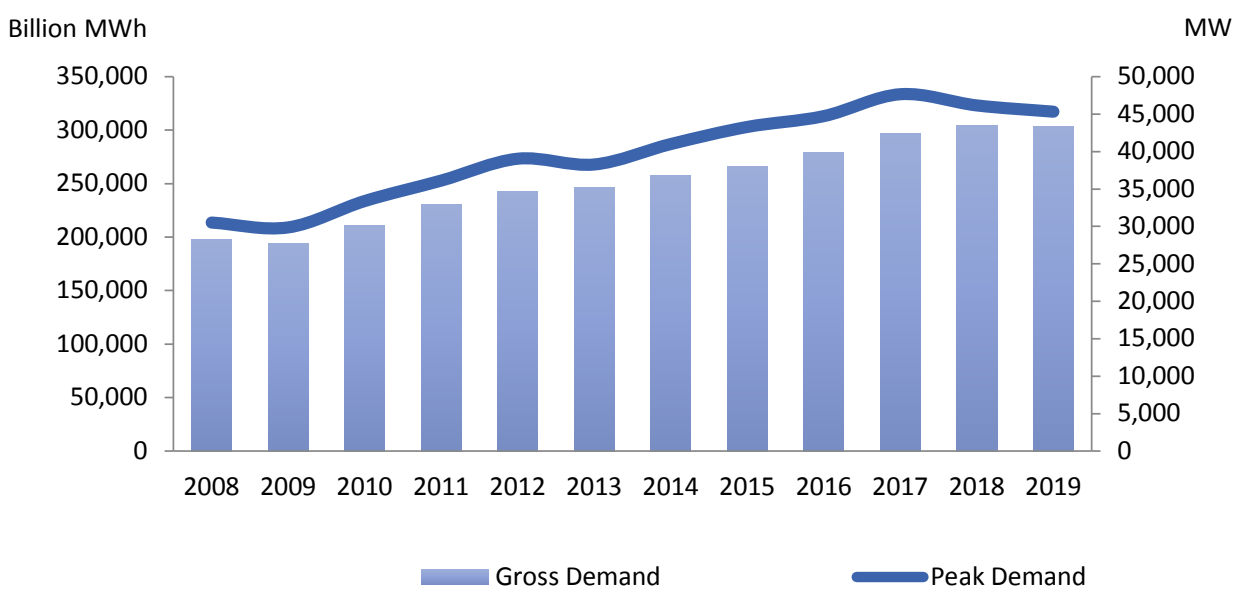

Figure 5 Changes in Turkey's electricity gross demand and peak demand values.

However, Turkey's gross electricity production reached 303.8 billion kWh according to provisional data at the end of 2019. Although electricity demand has decreased by 1 billion $\mathrm{kWh}$ compared to the 
previous year due to the general economic recession in the world; Turkey's energy usage is expected to increase $50 \%$ over the next decade. In 2019, when we look at the distribution of resources of Turkey's electricity production; $20 \%$ from imported coal, $17 \%$ from domestic coal, $18 \%$ from natural gas, $29.2 \%$ from hydroelectric sources, $7 \%$ from wind energy, 3.5\% from solar energy, $2.7 \%$ one from geothermal energy and 1.5\% from other sources (Figure 6).

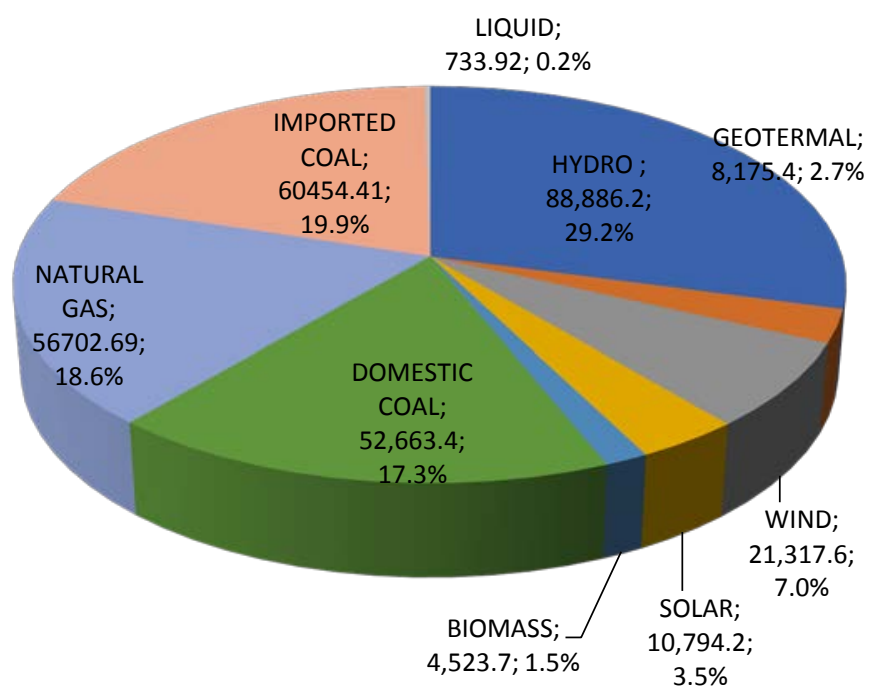

Figure 6 The distribution of the energy resources of Turkey's gross electricity generation in 2019.

Generating electricity from wind and solar power generation in Turkey, as can be seen from the Figure 6 is in constant increase. In the future, the majority of Turkey's electricity production with hydropower plants are not unlikely to be obtained from renewable energy sources. Turkey's electricity generation from various renewables containing dam type hydroelectric between 2000-2018 is in Figure 7.

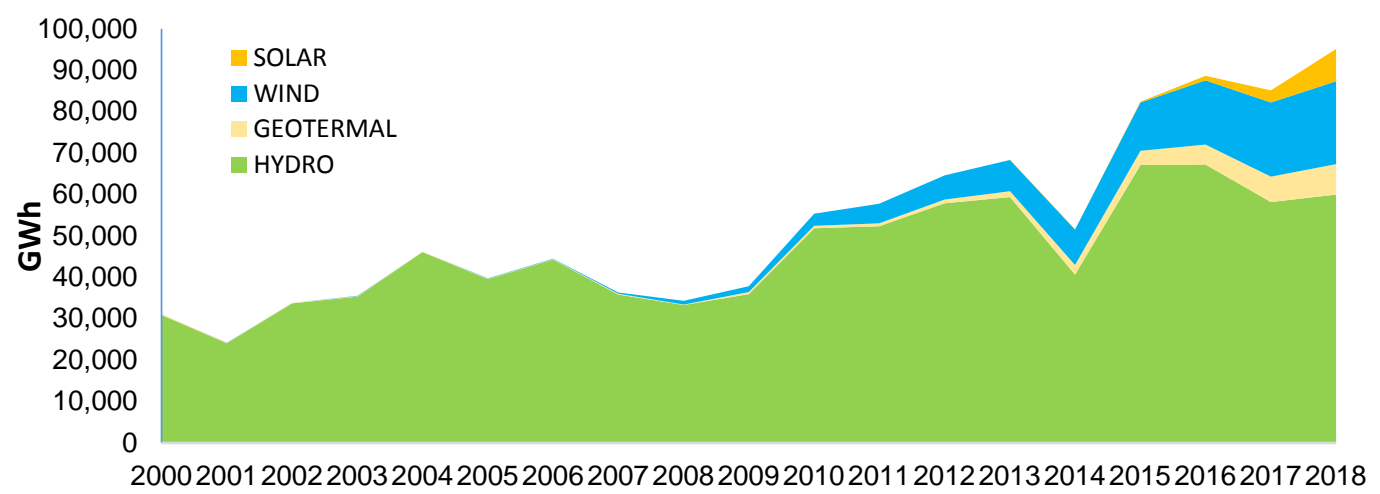

Figure 7 Turkey's electricity generation from various renewables including dam type hydros between 2000-2018 years.

\section{Covid-19 Effects On Turkey Power Generation}

Due to the country's emerging class of Turkey, in the periods outside crisis periods shows a steady upward trend in total electricity consumption. Turkey in the last three years (2017, 2018 and 2019) of electrical energy, when the gross production of months to examine the change in the last three years on the basis of all months except for one or two months, it is observed that compared to the same month of the previous year each year (Figure 8). 


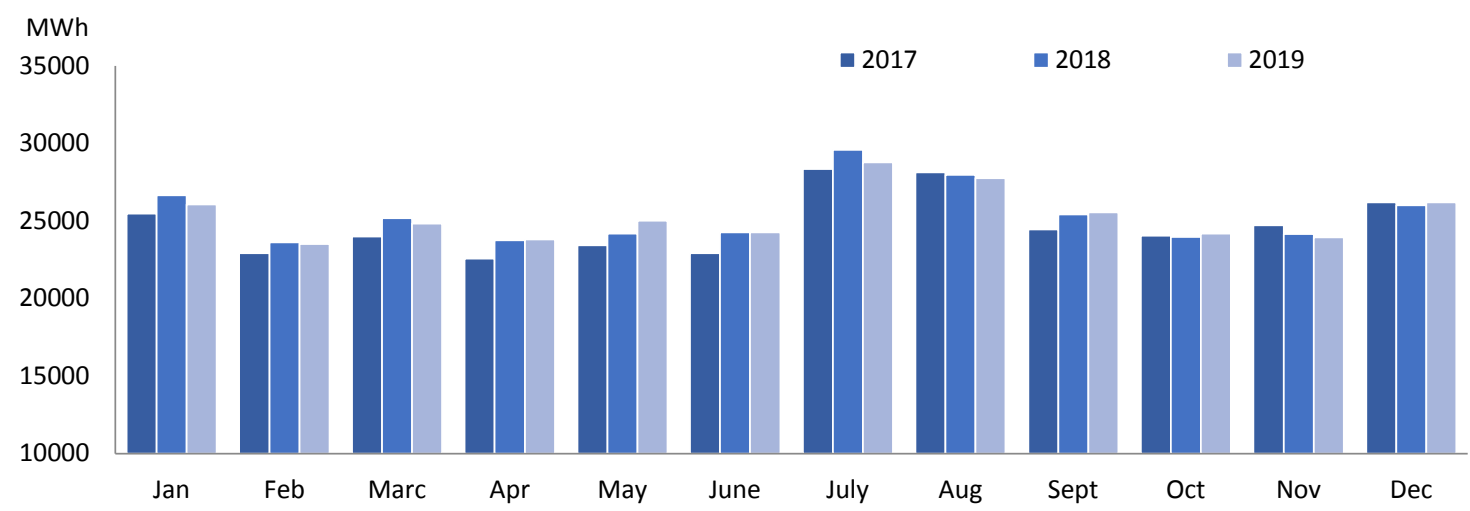

Figure 8 Turkey monthly change in the last three years of gross electricity production.

As expected, the total electricity consumption of the country started to increase rapidly in 2020, and the total electricity production in the first month of the year reached approximately 26.1 billion kWh with an increase of 3.91 percent compared to the same period of the previous year. Similarly, electricity consumption rose to 24.1 billion kWh in February 2020, with an increase of 5.98 percent compared to the same month of the previous year. This increase, which took place at the beginning of 2020, when we came to March, the increase in electricity demand started to stop due to the quarantine measures taken with the effect of the first case on March 11, 2020. With the effect of the measures taken in the Covid-19 process, the total electricity consumption in March 2020 was 23.6 billion kWh with a decrease of $-0.56 \%$. After that, electricity consumption in Turkey in April and May showed a rapid decline and electricity consumed near 19 billion kWh in April and 19.5 billion kWh in May. These values indicate a 15.5\% decrease compared to 22.6 billion kWh consumption in April 2019 and a 16.4\% decrease compared to 24.1 billion kWh consumption in May 2019 (Table 1).

Table 1 In the last three years with 7-month gross electricity production and exchange on a monthly the previous two years of electricity generation in 2020 by the Covid- 19 process in Turkey.

\begin{tabular}{|l|c|c|c|c|c|}
\hline Month & $\begin{array}{c}\mathbf{2 0 1 8} \\
\text { Production }\end{array}$ & $\begin{array}{c}\mathbf{2 0 1 9} \\
\text { Production }\end{array}$ & $\begin{array}{c}\mathbf{2 0 2 0} \\
\text { Production }\end{array}$ & Change by 2019 (\%) & Change by 2018 (\%) \\
\hline Jan & 25867,41 & 26058,60 & 26124,05 & 3,91 & 0,99 \\
\hline Feb & 22780,05 & 23522,12 & 24159,49 & 5,98 & 6,06 \\
\hline March & 24123,98 & 24843,57 & 23690,83 & $-0,56$ & $-1,80$ \\
\hline April & 22724,98 & 22560,96 & 19079,35 & $-15,56$ & $-16,04$ \\
\hline May & 22966,98 & 24176,75 & $19.577,41$ & $-16,48$ & $-14,76$ \\
\hline June & 22791,62 & 24258,08 & 22467,32 & $-2,61$ & $-1,42$ \\
\hline July & 29589,09 & 28789,66 & 28773,61 & $-0,06$ & $-2,76$ \\
\hline
\end{tabular}

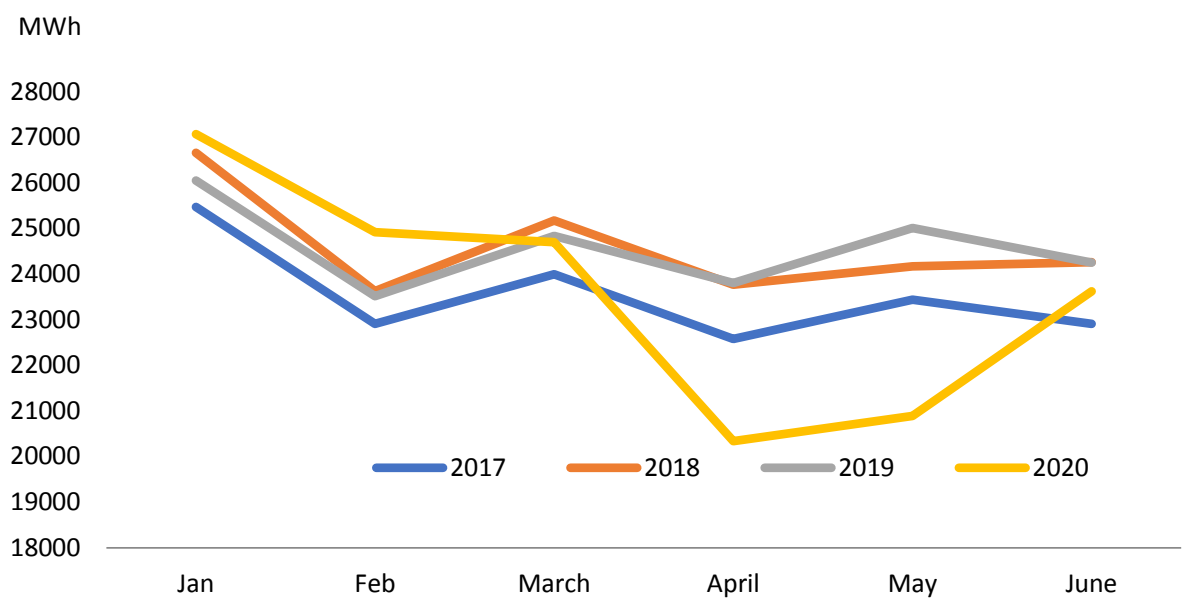

Figure 9 Change of 6-month gross electricity generation in 2020 compared to the same month of the last three years in Turkey. 


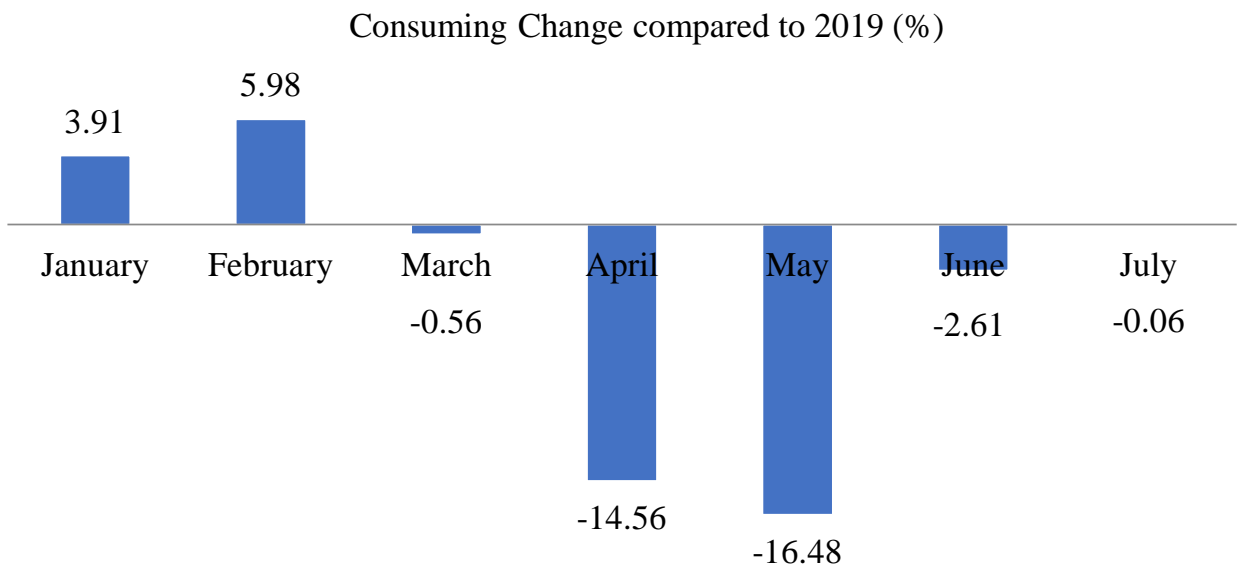

Figure 10 Turkey's monthly gross electricity production of 6-month change in 2020 compared to the same month of 2019.

Turkey's monthly gross electricity production of his first 7 months of 2020, compared with the last three months of the year Covid-19 electricity production process is clearly evident in some of the changes. Accordingly, with the month of March, when the first incident occurred, electricity generation started to decrease compared to 2019, and this decline reached peaks of $-15.56 \%$ and $16.48 \%$ in April and May, and the downward trend lost pace with the normalization step in June (Figures 9 and 10).

\section{Electricity Consumption And Source Change of Production in The Covid-19 Period}

When the electricity consumption in the following weeks with the week of March 11, 2020, when the first Covid-19 case was observed, demand decreased rapidly, the full quarantine measures continued to decrease until the week of June 1, 2020, when the normalization process was decided, and electricity consumption with the week containing this date It is observed that it started to increase again (Figure 11).

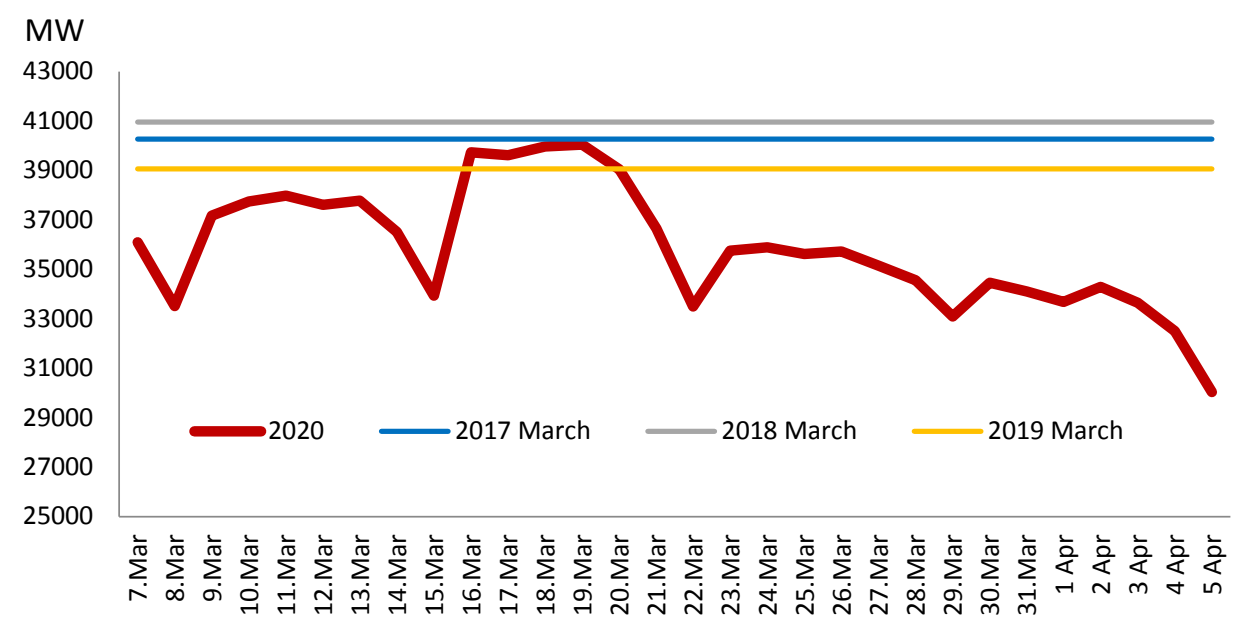

Figure 11 According to the maximum demand forces in March 2017-2019, Changing of daily peak demand power in March 2020.

Weekly Percent Change (HYD) values in electricity consumption were between 11th and 15th weeks when the first case was seen, March 11, 2020, and HYD1 = -19.3 between the 15th and 18th weeks, and the HYD2 $=-0.37$ between the weeks 15 and 18. After this week, electricity consumption has increased by $9 \%$ for 3 weeks and between the 18th week and the 20th week, HYD3 $=9.3$. Then, electricity consumption started to decline again, and between the 18th and 20th week, HYD4 = -13.3. 
Turkey's electricity demand between 19\% decrease of 15th week marks the 11th week, between the 11th week in 22nd week showed itself as a demand reduction of 23\% ( Figures 12 and 13).

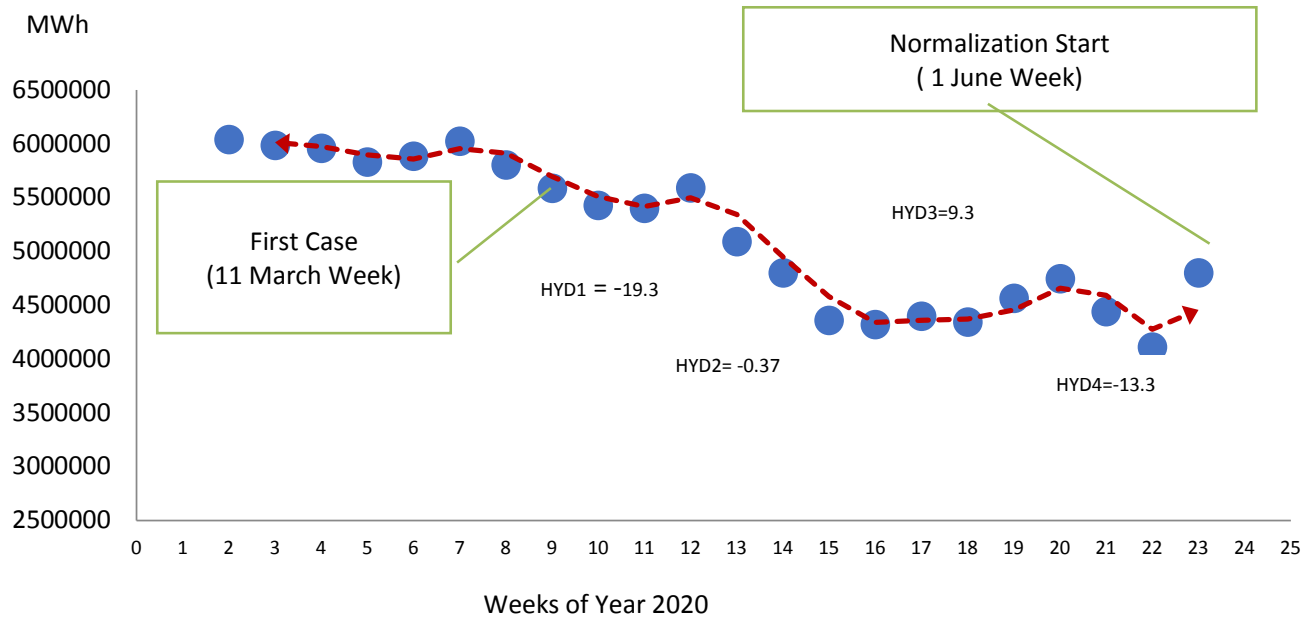

Figure 12 Turkey's electricity production in the weeks of between March-June 2020.

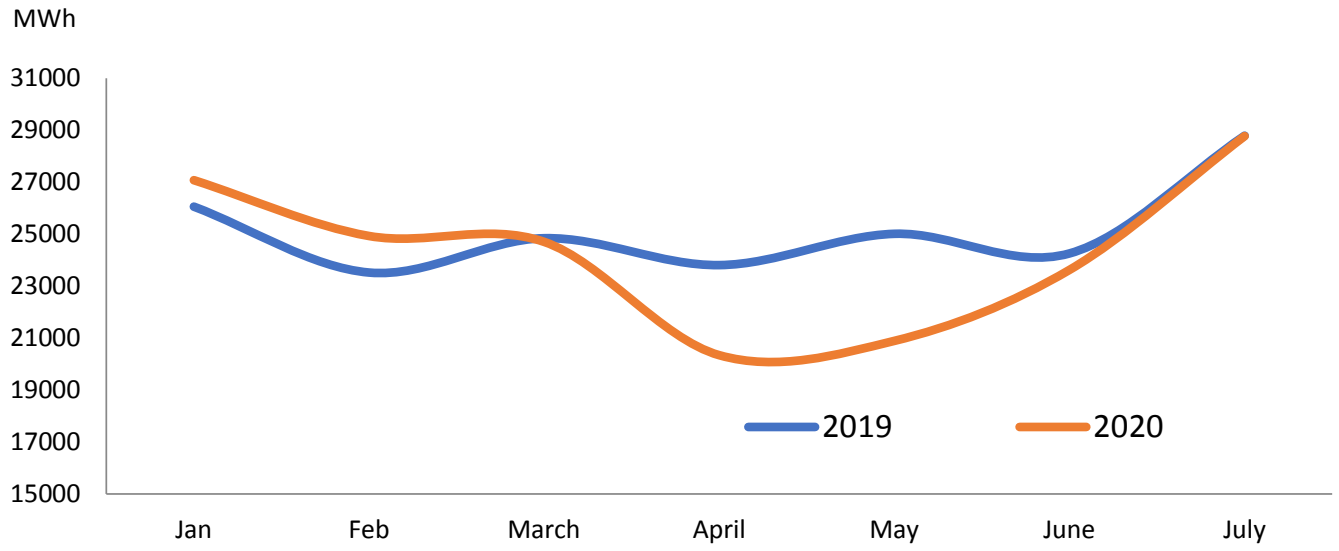

Figure 13 Covid-19 due to the decrease in electricity production in Turkey in 2020, changes that up to June 1, 2020 ceased to full quarantine.

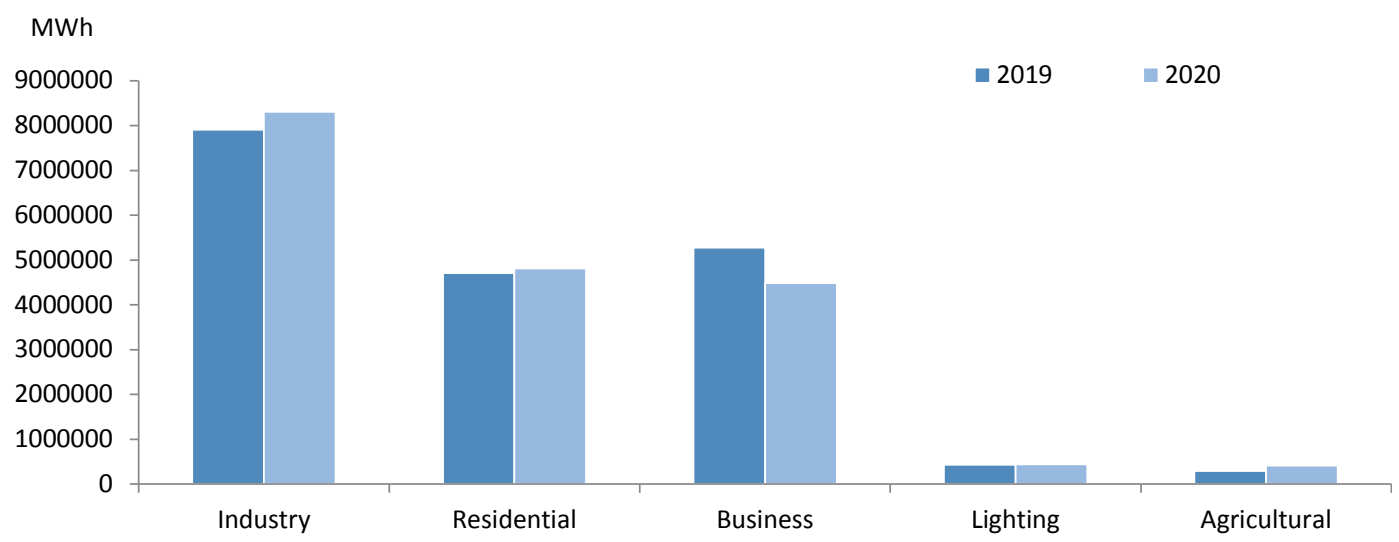

Figure 14 Comparison of the electricity consumption amount of subscribers in March 2020, when the first Covid-19 case was seen, with the March 2019 values.

Compared to the March 2019 values of the subscriber-based electricity consumption in March 2020, when the first Covid-19 case was observed, electricity consumption in residential and industrial areas increased in both amount and percentage, while a decrease of approximately $4 \%$, corresponding to the amount of 792 million kWh of electrical energy in business enterprises (Figure 14). While the first 
case did not affect industrial production on March 11, 2020, when it appeared, household electricity consumption increased by 105 million kWh with stay-at-home warnings, and it was observed that electricity consumption decreased due to the decrease in work or partial work in business enterprises.

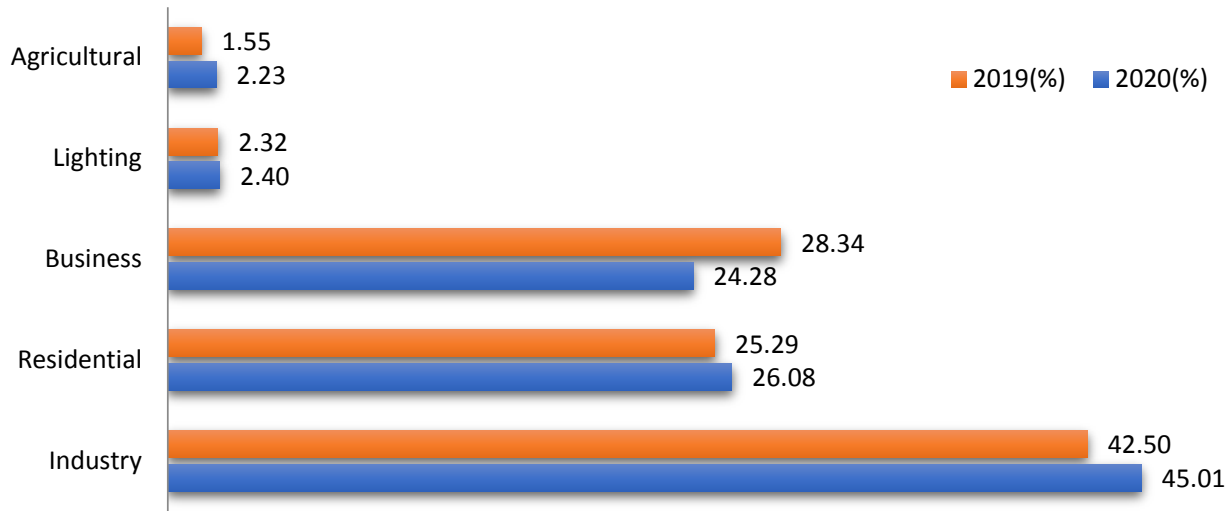

Figure 15 Comparison of the share of electricity consumption per subscriber in total consumption in March 2020, when the first Covid-19 incident was seen, with the March 2019 values.

According to the data that includes the analysis of electricity consumer behavior, household electricity consumption was shown in April compared to March, when the curfew began, while electricity consumption in businesses decreased. When looking at only March 2020, no significant change was observed based on lighting, while there was a $4.1 \%$ decrease in demand in businesses. Besides, with the effect of "stay at home" practices, an increase of $1.2 \%$ in domestic electricity consumption and $3 \%$ in industrial electricity consumption occurred (Figure 15). However, a consumption change directly proportional to the Covid-19 process is not observed in general lighting consumption.

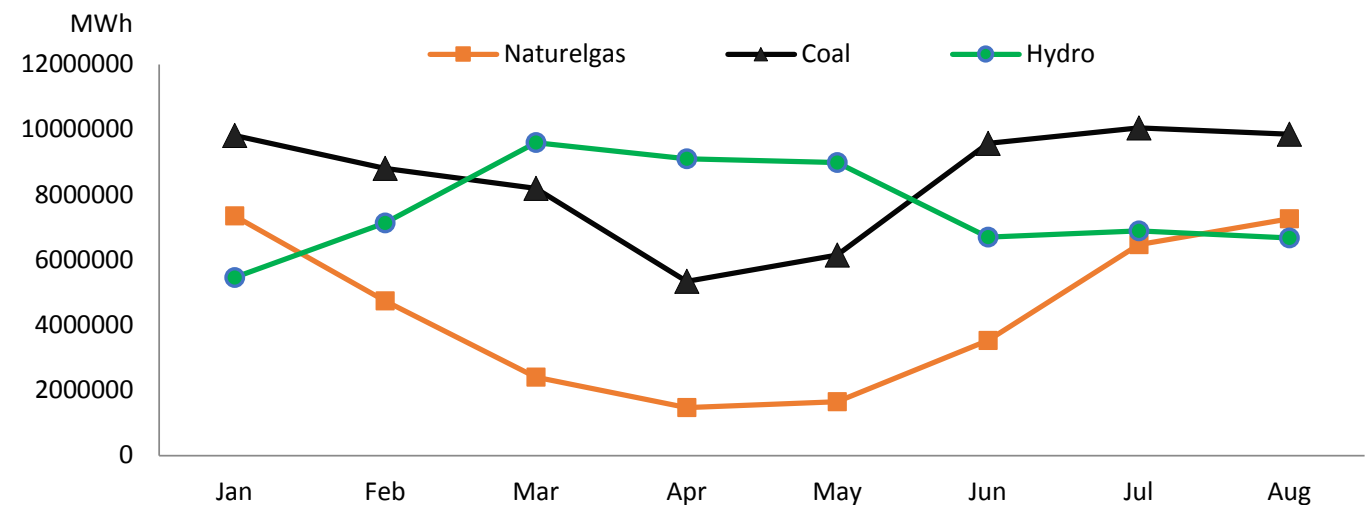

Figure 16 The change of resources used in the 8-month electricity generation in 2020 in the Covid 19 process.

The quarantine measures implemented with the start of the Covid-19 process have also been effective in the resources used in electricity generation. As can be seen in Figure 16, with the increase in the share of hydraulic power plants in electricity generation, electricity generation in coal power plants has decreased at an opposite rate to complement each other. Covid-19 process March starting in 2020 caused by falling consumption until July 2020 Turkey in the decline in the total gross power generation, there is provided by decreasing the production of power plants based on natural gas for welding (Figure 17).

When the fossil fuels used in electricity production are analyzed, it is observed that the share of natural gas decreased by 7\% in March 2020 from 17\% in 2019 to 10\%, from 13\% in April to 8\% and from $12 \%$ in May. The biggest change in electricity generation occurred in natural gas (Figure 17). In the Covid-19 process, the share of coal (asphaltite, lignite, hard coal and imported coal) used in electricity production in 2020 was compared with the values of 2019 monthly, the share in electricity 
generation did not change significantly, and its share in electricity generation was higher in June 2020, when the normalization process started (Figure 18).

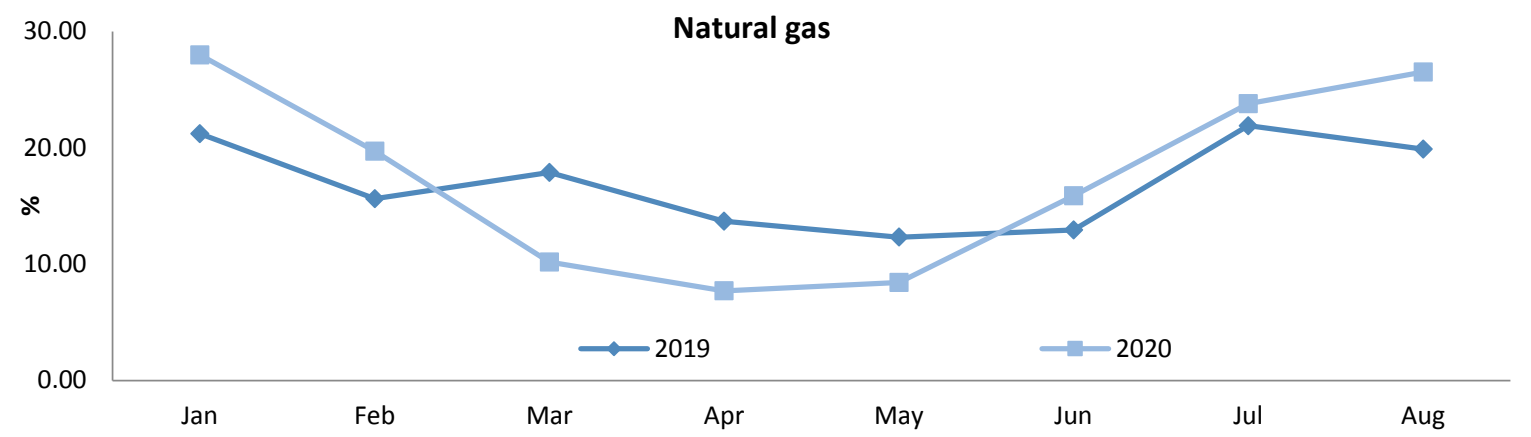

Figure 17 Comparison of the share of natural gas used in electricity generation in 2020 in the Covid 19 process, monthly with 2019 values.

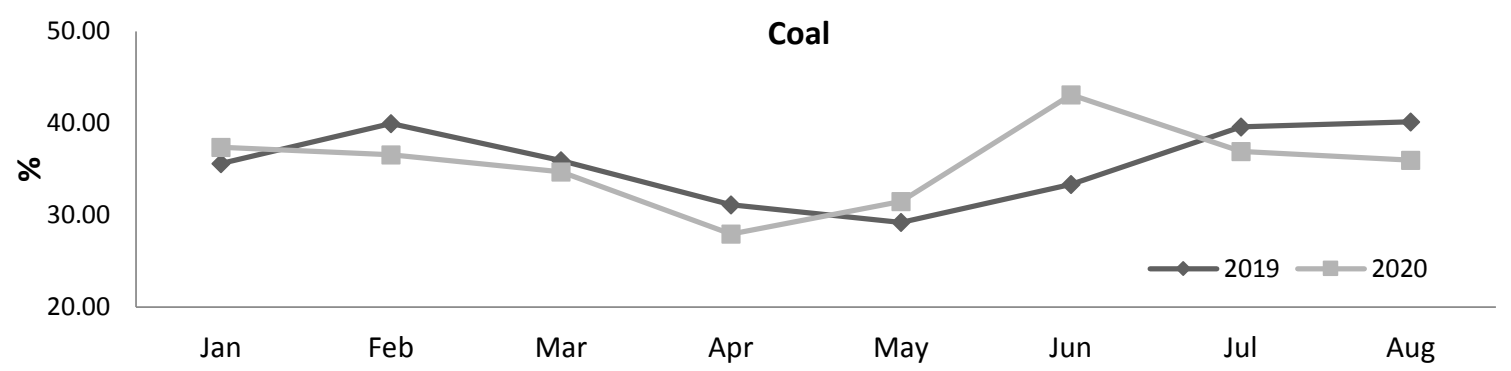

Figure 18 Comparison of the share of coal (asphaltite, lignite, hard coal and imported coal) used in electricity generation in 2020 in the Covid-19 process with 2019 values on a monthly basis.

The production of hydroelectric power plants, which are based on water revenues, increased in this period (Figure 19). Besides, between March 2020, when the decrease in electricity consumption occurred, and July 2020, the production of renewable energy power plants based on solar energy was not affected, and production increases due to capacity increase occurred (Figure 20).

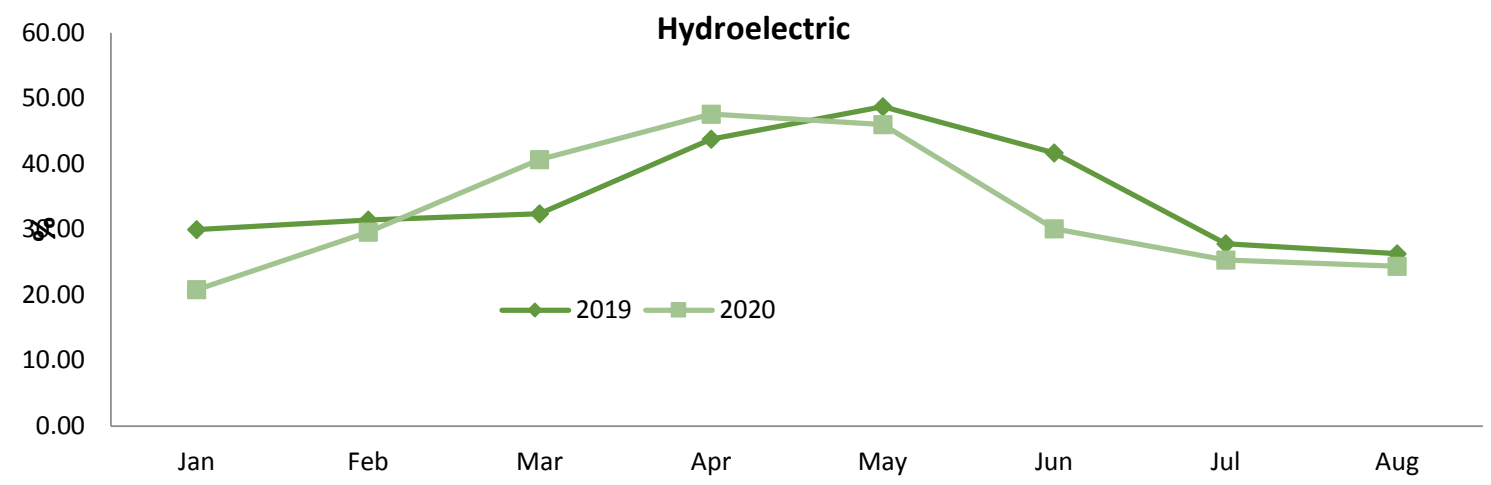

Figure 19 Comparison of the share of hydroelectric used in electricity generation in 2020 with the monthly values of 2019 in the Covid-19 process.

Covid-19 period, Turkey's total gross electricity between the decline occurred as the March 2020 July 2020 months in consumption, while the fall in electricity production from renewable energy plants based on wind power despite the annual capacity increase is thought to be due to the connected wind energy exchange of meteorological phenomena (Figure 21). Looking at the distribution of the resources of Turkey's electricity production in 7 months of 2020, generally it is seen as being unaffected by Covid-19 process of electricity generation based on renewable energy sources. 


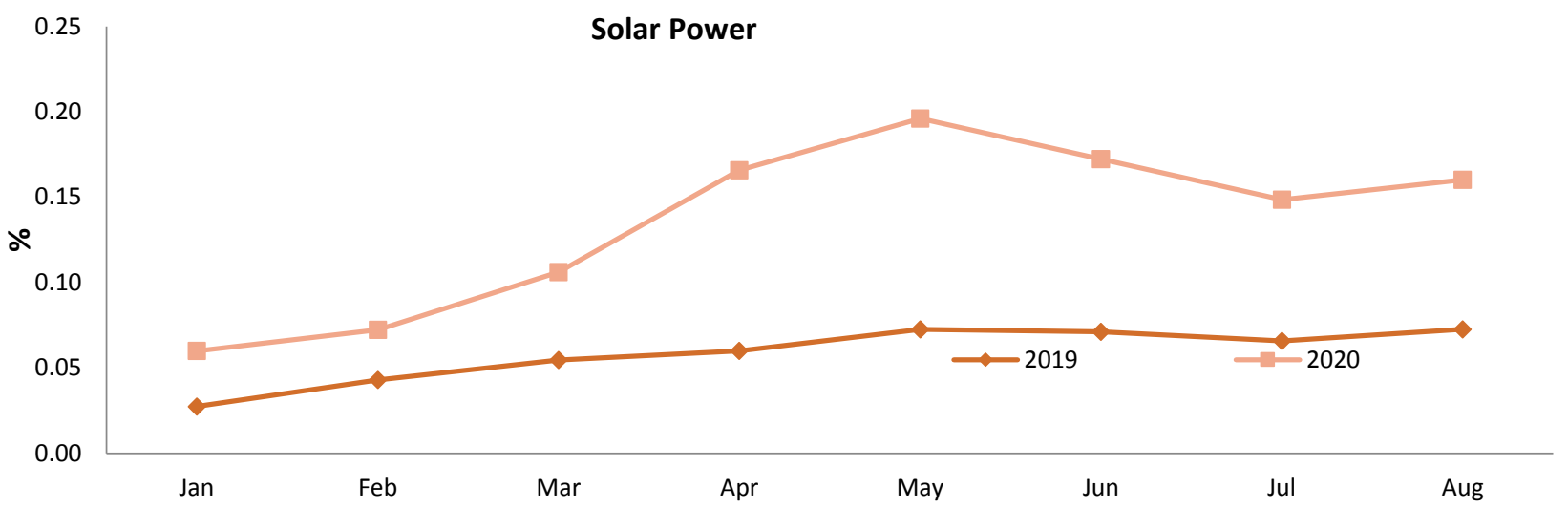

Figure 20 Comparison of the share of solar power plants used in electricity generation in 2020 in the Covid 19 process with the monthly values of 2019.

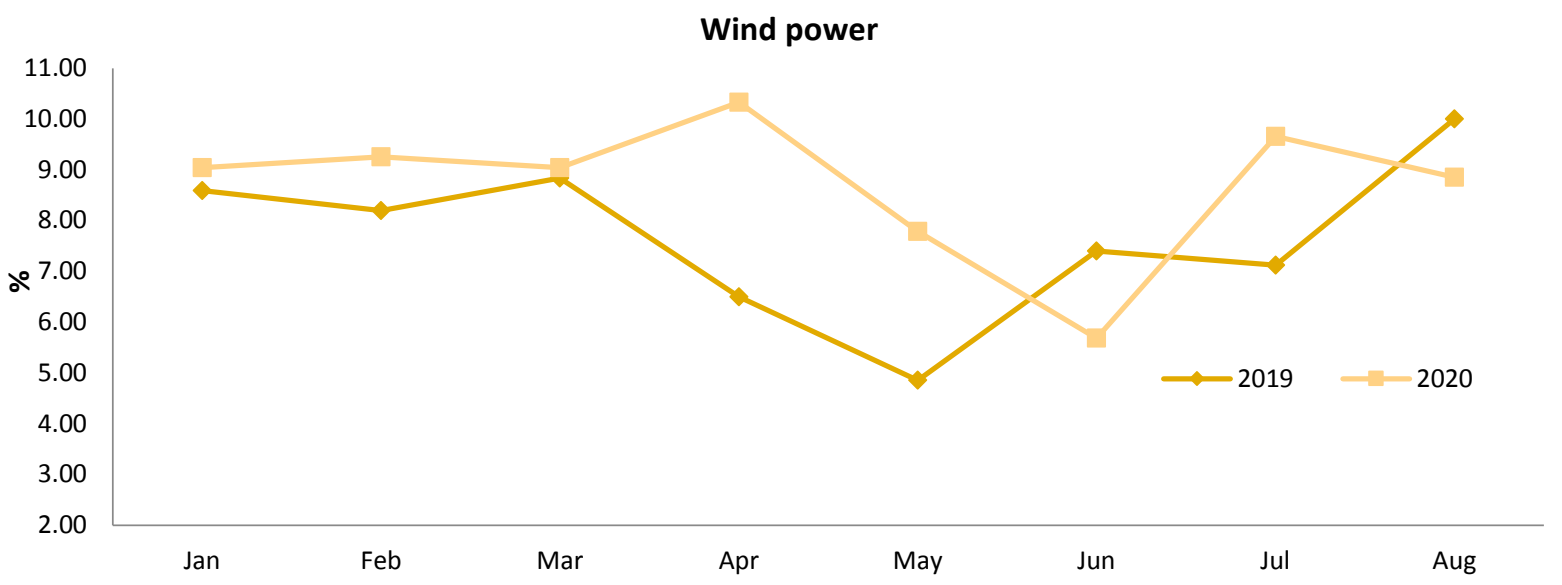

Figure 21 Comparison of the share of wind power plants used in electricity generation in 2020 in the Covid19 process, monthly with 2019 values.

\section{Results And Recommendations}

Due to the restriction of social and economic activity caused by the coronavirus outbreak it seems to be a decrease in Turkey's electricity demand. Although isolation practices throughout Turkey with the administration's restaurants, followed by cafes and other small businesses closing instructions, the economic activities in the country after staying in grocery stores and pharmacies are open and have declined sharply and this has affected the electricity consumption by lowering direction. During this period, some businesses started to consume more electrical energy, but the electrical energy they consume decreased as most of them had to stop or slow down their businesses. March 11, 2020, from the date shown in the new type of coronavirus country, the electricity consumption growth trend began residential subscribers in Turkey. On account of the measures taken against the coronavirus epidemic, with the effect of the increase in the rate of working from home and staying at home, electricity consumption in business centers decreased, while the increase in electricity consumption in residential groups continued to show its effect in April after March.

If the low levels of electricity consumption in countries continue, it will negatively affect the production of fossil fuel plants due to limited production and reduced incomes. However, in terms of solar, wind, hydraulic and other renewable power plants, since the electricity produced by them is first sent to the grid, they have no obstacles to their operation, as a result, the penetration of renewable energy in the electricity grids will reach the highest levels. Analysis of electricity consumption trends in countries due to the Covid-19 process has had significant effects on behavioral changes in the short and long term. 


\section{References}

[1] I. Dincer, “Covid-19 coronavirus: Closing carbon age, but opening hydrogen age”, Int J Energy Res., vol. 44. pp. 6093-6097, 2020. https://doi.org/10.1002/er.5569.

[2] T. Mylenka, "Impact of Covid 19 on the global energy sector", 2020. [Online]. Available: www.pv-magazine.com/2020/04/24/impact-of-covid-19-on-the-global-energy-sector. [Accessed: 09-Aug-2020].

[3] IEA, "COVID-19. Exploring the impacts of the Covid-19 pandemic on global energy markets, energy resilience, and climate change,” 2020. [Online]. Available:

https://www.iea.org/reports/global-energy-review-2020. [Accessed: 10-Aug-2020].

[4] M. Narajewski, F.Ziel, "Changes in electricity demand pattern in Europe due to COVID-19 shutdowns”, IAEE Energy Forum. (Special issue), pp. 44-47, 2020.

[5] M. Williamson, A. Zaman, "COVID-19 crisis reinforces the importance of the sustainable energy transition,” 2020. [Online]. Available: https://www.unescap.org/blog/covid-19-crisisreinforces-importance-sustainable-energy-transition. [Accessed: 10-Aug-2020].

[6] M. Narajewski , F. Ziel, "Changes in Electricity Demand Pattern in Europe Due to COVID-19 Shutdowns”, IAEE Energy Forum , Covid-19 Issue, 2020. [Online]. Avaliable: https://www.iaee.org/en/publications/newsletterdl.aspx?id=883, [Accessed: 10-Sep-2020].

[7] M. Bulut, "Editorial: Effects of New Normal Life on Electricity Consumption in Covid-19 Process”, Journal of Scientific, Technology and Engineering Research, vol. 1, no. 1, pp. 4-6, 2020. DOI: 10.5281/zenodo.3902885

[8] TEIAŞ (Turkish Electricity Transmission Co.), “Turkey Electricity Production and Transmission Statistics”, 2020. [Online]. Avaliable: https://www.teias.gov.tr/tr-TR/turkiyeelektrik-uretim-iletim-istatistikleri. [Accessed: 10-Aug-2020].

[9] TEIAŞ (Turkish Electricity Transmission Co), "Load Dispatch Information System (YTBS)”, 2020. [Online]. Avaliable: https://ytbsbilgi.teias.gov.tr/ytbsbilgi/frm_istatistikler.jsf. [Accessed: 5-Sep-2020].

[10] EMRA (Energy Market Regulatory Authority , "Electricity Market Official Statistics List”, 2020. [Online]. Avaliable: www.epdk.gov.tr/Detay/Icerik/3-0-167/resmi-istatistikleri. [Accessed: 15-Sep-2020].

[11] TEDAŞ (Turkey Electricity Distribution Corporation ), "Information Center, General Lighting Consumption,” 2020. [Online]. Avaliable : https://www.tedas.gov.tr/\#!tedas_tarifeler_1, [Accessed : 5-Sep-2020].

[12] EPİAȘ (Turkish Energy Exchange), “Exist Transparency Platform,” 2020. [Online]. https://seffaflik.epias.com.tr/transparency/index.xhtml. [Accessed: 3-Sep-2020]. 
[13] TEIAȘ (Turkish Transmission System Operator), Annual Report, pp. 35, 2009.

[14] ISE, “Fraunhofer Institute for Solar Energy Systems”, 2020. [Online]. Avaliable: www.energy-charts.de/power_inst.htm. [Accessed: 15-Jul-2020]. 